\section{Prevalence of thyroid diseases in patients with acromegaly - Experience of a Brazilian center}

\author{
Prevalência das doenças tireoidianas em pacientes com \\ acromegalia - Experiência de um centro brasileiro
}

Helena Bandeira de Melo Paiva Uchoa', Giovanna Aparecida Balarini Lima',2, Lívia Lugarinho Corrêa', Ana Paula Sieiro Vidal', Suzana Aquino Cavallieri', Mário Vaisman', Alexandru Buescu', Mônica Roberto Gadelha'

\begin{abstract}
Objectives: Acromegaly is frequently associated with thyroid diseases. In this study, we evaluated the frequency of thyroid disorders in a series of acromegalic patients. Subjects and methods: We evaluated 106 acromegalic patients using thyroid ultrasonography (US) and measurements of GH, IGF-I, free T4, TSH and anti-thyroperoxidase antibody levels. IGF-I was expressed in mass units and age-related standard deviation scores (SD-scores). Fine-needle aspiration biopsy (FNAB) was performed on thyroid nodules with a diameter greater than one centimeter or with suspicious characteristics. Results: Thyroid disorders were found in 75 patients. Eleven patients had diffuse goiter, 42 patients had nodular goiter, and 22 patients had unspecific morphological abnormalities. Four patients $(3.8 \%)$ had thyroid carcinoma. Considering the patients with diffuse or nodular goiter, thyroid volume was greater in patients with active acromegaly, and was positively correlated with GH, IGF-I, and IGF-I SD-score. Conclusions: Our study confirmed that benign thyroid diseases are frequent in acromegalic patients. The prevalence of thyroid cancer was higher than in the overall population. We suggest that thyroid US should be routinely performed in patients with acromegaly. Arq Bras Endocrinol Metab. 2013;57(9):685-90
\end{abstract}

Keywords

Acromegaly; thyroid; goiter; cancer

\section{RESUMO}

Objetivos: Acromegalia está frequentemente associada a doenças tireoidianas. Neste estudo, avaliamos a presença de tireoidopatias em uma série de pacientes acromegálicos. Sujeitos e métodos: Foram avaliados 106 pacientes por ultrassonografia (US) e dosagens de GH, IGF-1, T4 livre TSH e anticorpo antitireoperoxidase. O IGF-I foi expresso em unidades de massa e desvio-padrão (DP-IGF-I). Punção aspirativa por agulha fina (PAAF) foi realizada quando os nódulos eram maiores que um centímetro ou tinham características suspeitas. Resultados: Alterações tireoidianas foram encontradas em 75 pacientes. Onze apresentavam bócio difuso, 42, bócio nodular e 22, alterações morfológicas inespecíficas. Houve quatro casos $(3,8 \%)$ de câncer diferenciado de tireoide. Considerando os pacientes com bócio difuso ou nodular, o volume tireoidiano foi maior naqueles com acromegalia em atividade e correlacionou-se positivamente com os níveis de GH, IGF-1 e DP-IGF-1. Conclusões: Nosso estudo confirmou que as doenças tireoidianas benignas são frequentes nos pacientes acromegálicos. A prevalência de câncer diferenciado de tireoide foi maior que na população geral. Sugerimos que US de tireoide seja realizado rotineiramente nos pacientes com acromegalia. Arq Bras Endocrinol Metab. 2013;57(9):685-90

\section{Descritores}

Acromegalia; tireoide; bócio; câncer
Division of Endocrinology, Hospital Universitário Clementino Fraga Filho, Universidade Federal do Rio de Janeiro (HUCFF/UFRJ), Rio de Janeiro, RJ, Brazil

2 Division of Endocrinology, Hospital Universitário Antônio Pedro, Universidade Federal Fluminense (UFF), Niterói, RJ, Brazil ${ }^{3}$ Labs D'Or Laboratório e Imagem, Rio de Janeiro, RJ, Brazil

\section{INTRODUCTION}

cromegaly is an uncommon disease that is usual-
ly caused by a growth hormone (GH)-secreting pituitary adenoma (1), and is associated with a 1.7-fold increase in mortality (2). The major causes of death include cardiovascular, cerebrovascular, and respiratory disease (3-8). Several studies have indicated that acromegalic patients also have an increased risk of developing both benign and malignant tumors (9-11). 
It is well-established that acromegaly is associated with an increased prevalence of goiter (12-19). Thyroid follicular cells express IGF-I receptors (21), and the continuous exposure of thyroid cells to the chronic effect of high IGF-I levels may be involved in goiter development. Several authors found a positive relationship between thyroid volume and high serum levels of IGF-I (12-20). Several studies have found an increased prevalence of nodular goiter and thyroid carcinoma $(14,16,18-20,22,23)$ in acromegalic patients. A Brazilian study of 34 consecutive patients with acromegaly recently demonstrated that $67 \%$ of the patients had thyroid nodules and $11 \%$ had differentiated thyroid carcinoma (24). In this study, we evaluated the frequency of thyroid disorders in a series of acromegalic patients and correlated the occurrence of thyroid disorders with disease activity.

\section{METHODS}

\section{Patients}

The study group consisted of 106 patients with acromegaly recruited from the outpatient endocrinology clinic of the Hospital Universitário Clementino Fraga Filho (HUCFF) of the Universidade Federal do Rio de Janeiro (UFRJ) over a 12-month period. Reasons for ineligibility were pregnancy, thyroid nodular diseases diagnosed before acromegaly, and patients previously submitted to total thyroidectomy. All subjects entered the study after written informed consent was signed, according to a protocol approved by the Ethics Committee of the HUCFF.

\section{Laboratory diagnosis of acromegaly}

Acromegaly diagnosis was based on the following criteria: 1 ) a lack of suppression of $\mathrm{GH}$ to below $\mathrm{l} \mathrm{ng} / \mathrm{mL}$ after the oral administration of $75 \mathrm{~g}$ glucose; and 2) high levels of serum IGF-I.

\section{Clinical parameters}

After documentation of age, sex, estimated acromegaly duration (determined from the time of the onset of signs and symptoms to the time of inclusion in the stu$\mathrm{dy}$ ), and an inquiry concerning the signs and symptoms of thyroid disorders, all patients underwent clinical examination of the thyroid gland by the same physician (H.B.M.P.U.).

\section{Hormone assays}

Serum GH, IGF-I, free T4 (fT4), TSH and anti-thyroperoxidase antibody (anti-TPO Ab) levels were determined by chemiluminescent immunometric assays (Diagnostic Products Corporation-DPC, Los Angeles, CA) with the IMMULITE 2000 analyzer. IGF-I level was expressed in mass units and age-related standard deviation scores (SD-scores). The IGF-I SD-score was calculated according to Elmlinger and cols. (25). The reference values were $0.89-1.76 \mathrm{ng} / \mathrm{dL}$ for fT4, 0.355.50 for TSH and $<35 \mathrm{UI} / \mathrm{mL}$ for anti-TPO Ab.

All serum samples were collected early in the morning, after an eight-hour fasting period.

\section{Thyroid ultrasound}

Thyroid ultrasonography was performed by the same practitioner (S.A.C.) using a HDI 5000, ATL (Advanced Technology Laboratories, Bothell, WA), Phillips, 2003, with a 7-12 MHz transducer. Thyroid volume was calculated by the elliptical shape volume formula ( $\pi / 6 \mathrm{x}$ length $\mathrm{x}$ width $\mathrm{x}$ thickness). Total volume was determined by the sum of each lobe and isthmus. Goiter was defined as thyroid volume exceeding $12.6 \mathrm{~cm}^{3}$ for women, and $17.1 \mathrm{~cm}^{3}$ for men (26).

Morphology was classified in four categories: normal gland, unspecific morphological abnormalities (colloid cyst or heterogeneous texture) and diffuse and nodular goiter (uni- or multinodular).

\section{Fine-needle aspiration biopsy (FNAB)}

FNAB was performed on all thyroid nodules with a diameter greater than one centimeter, or on nodules that displayed two or more suspicious characteristics in the ultrasound. All FNABs were performed by the same practitioner (S.A.C.), and were guided by ultrasonography. The cytopathological analysis was performed by the same pathologist (A.P.A.V.), and the results were classified according to the Bethesda system (27).

When the patients were submitted to thyroidectomy, all specimens were reviewed by the same pathologist (A.P.A.V.). Thyroid cancer was staged using TNM classification (tumor, lymph node, and distant metastasis) (28).

\section{Statistical analysis}

Analyses were performed by SPSS (version 11.0 for Windows; Chicago, IL). Results are expressed as the 
median (minimum-maximum). Comparisons between categorical variables were performed using Fisher's exact test. Comparisons between numerical variables were performed using the Mann-Whitney test. Correlations were determined by calculating Spearman's rank correlation coefficient. P values $<0.05$ were considered statistically significant.

\section{RESULTS}

\section{Study population}

The main characteristics of the study population are described in table 1 .

Table 1. Clinical characteristics of the 106 acromegalic patients

\begin{tabular}{ll}
\hline Patient characteristics & \\
\hline Sex & Female: $62(58.5 \%)$ \\
Age & $46.5(25-81)$ years \\
GH & $3.5(0.15-68) \mathrm{ng} / \mathrm{mL}$ \\
IGF-I & $381.5(56-1,600) \mathrm{ng} / \mathrm{mL}$ \\
IGF-I SD-score & $3.5(-4.5-8.5)$ \\
Acromegaly duration & $10.5(1-25)$ years \\
Tumor size & Macroadenoma*: $91(85.8 \%)$ \\
Acromegaly control** & Yes: $32(30.2 \%)$ \\
\hline
\end{tabular}

Data are shown as medians (minimum-maximum). ${ }^{*}$ Adenoma $>10 \mathrm{~mm} .{ }^{*}$ Basal $\mathrm{GH}<2.5 \mathrm{ng} / \mathrm{mL}$ and normal IGF-I.

\section{Thyroid abnormalities}

Functional and morphological thyroid evaluations were performed in all 106 patients. Nineteen patients presented secondary hypothyroidism, and nine patients presented primary hypothyroidism (anti-TPO Ab was positive in eight of them). Of the patients with primary hypothyroidism, two had subclinical hypothyroidism and were not being treated. Two patients had history of hyperthyroidism.

Thyroid morphology abnormalities at ultrasound were observed in 75 patients (71.0\%). Eleven patients (10.4\%) had diffuse goiter, $42(40.0 \%)$ had nodular goiter, and 22 patients $(20.6 \%)$ had unspecific morphology abnormalities (colloid cyst or heterogeneous texture). The two patients with TSH levels above the reference value presented subclinical hypothyroidism and unspecific morphology abnormalities.

Fine-needle aspiration biopsy was performed in 22 patients, and the other 20 patients did not meet the criteria for FNAB. The Bethesda system of classification showed one unsatisfactory result (Bethesda I); 10 benign
(Bethesda II); three follicular lesions of undetermined significance (Bethesda III); four follicular neoplasms (Bethesda IV); one suspicious for malignancy (Bethesda V); and three malignant lesions (Bethesda VI). Among the patients with follicular lesions, three patients underwent thyroidectomy: two had nodular hyperplasia, one had papillary carcinoma, and five were not submitted to surgery (two refused it, and three are in a waiting list).

Considering the five patients that were not operated on, three of them presented Bethesda III lesions, and two presented Bethesda IV lesions. Morphological thyroid evaluation is described in table 2 . Four patients (3.8\%) had thyroid carcinoma (two multifocal papillary carcinomas, one papillary variant of follicular carcinoma, and one papillary microcarcinoma). Two of the thyroid carcinoma patients were females, with a median age of 51 years, and two of the patients had active acromegaly at the time of the thyroid carcinoma diagnosis. The clinical characteristics of the patients with thyroid carcinoma are described in table 3.

The group of patients with morphological abnormalities (group 2, $\mathrm{n}=75$ ) showed a greater number of women ( 52 vs. 10, $\mathrm{p}=0.001)$, older patients (49 vs. 45 years-old, $\mathrm{p}=0.033)$, and greater thyroid volume (12.9 vs. $9.1 \mathrm{~cm}^{3}, \mathrm{p}=0.002$ ) compared with the group of patients with a normal thyroid gland at ultrasound (group $1, \mathrm{n}=31$ ). No difference was found considering the following parameters: disease control, estimated acromegaly duration, IGF-I, IGF-I SD-score, GH, fT4 or TSH (Table 4).

Table 2. Morphological thyroid evaluation of 106 acromegalic patients

\begin{tabular}{|c|c|c|c|}
\hline $\begin{array}{l}\text { Thyroid morphology in } \\
\text { ultrasonography }\end{array}$ & n (\%) & n (Female) & n (Male) \\
\hline Normal & $31 / 106(29.0 \%)$ & 11 & 20 \\
\hline Diffuse goiter & $11 / 106(10.4 \%)$ & 11 & 0 \\
\hline Nodular goiter & $42 / 106(40.0 \%)$ & 24 & 18 \\
\hline Uninodular goiter & $8 / 106(7.5 \%)$ & 4 & 4 \\
\hline Multinodular goiter & $34 / 106(32.5 \%)$ & 20 & 14 \\
\hline $\begin{array}{l}\text { Unspecific morphology } \\
\text { abnormalities }\end{array}$ & 22/106 (20.6\%) & 12 & 10 \\
\hline \multicolumn{4}{|c|}{ Fine-needle aspiration biopsy } \\
\hline Benign & $10 / 22(45.5 \%)$ & 6 & 4 \\
\hline Follicular lesions & $8 / 22(36.4 \%)$ & 2 & 6 \\
\hline Papillary carcinoma & $3 / 22(13.6 \%)$ & 2 & 1 \\
\hline Unsatisfactory & $1 / 22(4.6 \%)$ & 0 & 1 \\
\hline \multicolumn{4}{|l|}{ Histological examination } \\
\hline Benign nodular hyperplasia & $2 / 6(33.3 \%)$ & 0 & 2 \\
\hline Papillary carcinoma & $4 / 6(66.7 \%)$ & 2 & 2 \\
\hline
\end{tabular}


Table 3. Characteristics of the patients with thyroid carcinoma

\begin{tabular}{lcccccc}
\hline Patient & Sex & Age (years) & $\begin{array}{c}\text { Duration of } \\
\text { acromegaly } \\
\text { (years) }\end{array}$ & $\begin{array}{c}\text { Acromegaly } \\
\text { control }\end{array}$ & FNAB & Histopathology \\
\hline$\# 1$ & Male & 49 & 13 & Yes & Papillary carcinoma & Multifocal papillary carcinoma \\
$\# 2$ & Female & 56 & $1 / 3$ & No & Papillary carcinoma & Multifocal papillary carcinoma \\
$\# 3$ & Female & 63 & $2 / 9$ & Yes & Papillary carcinoma & Papillary carcinoma (follicular variant) \\
$\# 4$ & Male & 36 & 13 & No & Follicular tumor & Papillary microcarcinoma \\
\hline
\end{tabular}

FNAB: fine-needle aspiration biopsy.

Table 4. Comparison of acromegalic patients without $(n=31$, group 1) and with ( $n=75$, group 2) thyroid diseases (nodular goiter, diffuse goiter, and unspecific morphology abnormalities)

\begin{tabular}{lccc}
\hline & Group 1* & Group 2* & p value \\
\hline Age (years) & $45(27-66)$ & $49(25-81)$ & 0.033 \\
Acromegaly duration (years) & $8.50(1-25)$ & $10(2-23)$ & 0.24 \\
T4L (RV: $0.89-1.76 \mathrm{ng} / \mathrm{dL})$ & $1.19(0.87-1.63)$ & $1.20(0.62-1.90)$ & 0.65 \\
TSH (RV: $0.35-5.50 \mathrm{mUI} / \mathrm{L})$ & $1.18(0.05-10.90)$ & $1.030(0.004-15.800)$ & 0.31 \\
IGF-I (ng/mL) & $368(104-1600)$ & $391(56-1252)$ & 0.70 \\
IGF-I SD-score & $3.38(-1.84-8.45)$ & $3.97(-4.47-8.07)$ & 0.55 \\
GH (ng/mL) & $2.80(0.15-40.00)$ & $3.71(0.18-68.00)$ & 0.26 \\
Acromegaly control** & Yes: $9 / 22(41.00 \%)$ & Yes: $23 / 52(44.20 \%)$ & 0.53 \\
Thyroid Volume (RV: women $<12.6 \mathrm{~cm}^{3}$, men $\left.<17.1 \mathrm{~cm}^{3}\right)$ & $9.10(6.40-18.30)$ & $12.90(6.20-56.50)$ & 0.002 \\
\hline
\end{tabular}

* Data are shown as medians (minimum-maximum). ${ }^{* *}$ Basal GH $<2.5 \mathrm{ng} / \mathrm{mL}$ and normal IGF-I. RV: reference value.

Considering only the patients with morphological abnormalities, thyroid volume was weakly correlated with IGF-I levels $(\mathrm{r}=0.255, \mathrm{p}=0.032)$ and IGF-I SD-score $(\mathrm{r}=0.250, \mathrm{p}=0.036)$. There was no correlation between thyroid volume and age, estimated acromegaly duration, fT4 or TSH. Thyroid volume in this group of patients was greater in the patients with active acromegaly $\left(13.7 v s .8 .9 \mathrm{~cm}^{3}, \mathrm{p}=0.033\right)$. In the patients with diffuse or nodular goiter, thyroid volume was greater in patients with active acromegaly $\left(15.30 \mathrm{vs} .8 .50 \mathrm{~cm}^{3}, \mathrm{p}\right.$ $=0.028)$, and was weakly correlated with GH levels $(\mathrm{p}$ $=0.032 ; \mathrm{r}=0.304)$, IGF-I $(\mathrm{p}=0.013 ; \mathrm{r}=0.347)$, and the IGF-I SD-score $(\mathrm{p}=0.017 ; \mathrm{r}=0.335)$. There was no correlation between thyroid volume and the duration of acromegaly. TSH levels were lower in patients with nodular disease $(0.73 \mathrm{mU} / \mathrm{L}$ vs. $1.18 \mathrm{mU} / \mathrm{L}, \mathrm{p}=$ $0.007)$. Five of the patients with lower TSH levels and nodular diseases $(n=6)$ had a pituitary macroadenoma, and all the six patients had secondary hypothyroidism with normal fT4 levels.

In the group of patients with morphological abnormalities, the patients with nodular or diffuse goiter $(\mathrm{n}=$ 53 ) had greater thyroid volume (14.7 vs. $12.9 \mathrm{~cm}^{3}, \mathrm{p}<$ $0.001)$ and longer estimated acromegaly duration than patients with unspecific morphology abnormalities (6 vs. 3 years, $\mathrm{p}=0.019$ ).

\section{DISCUSSION}

In this series of 106 patients with acromegaly, we found a $71 \%$ prevalence of thyroid disorders, including nodular and diffuse goiter and unspecific morphological abnormalities. The high prevalence is similar to the findings of previous studies $(15,20,24,29)$ and is supported by evidence that IGF-I-dependent, TSH-independent signaling is important for growth regulation of the thyroid gland in humans. In acromegaly, the high intrathyroidal IGF-I levels may contribute to goiter development (21). Two findings in our study support the role of IGF-I in the development of thyroid disorders in acromegaly: the positive correlation of IGF-I levels with thyroid volume and the lower TSH levels in patients with nodular goiters. All the patients with lower TSH levels and nodular goiter had secondary hypothyroidism and were on levothyroxine replacement, with normal fT4 levels. In a recent study, Rogozinski and cols. (24) evaluated 34 acromegalic patients and found high prevalence of nodular disorder $(67 \%)$. The- 
se patients had a longer history of acromegaly. Cheung and Boyages (12) and Miyakawa and cols. (20) described an important positive correlation between IGF-I levels and thyroid volume, while Kasagi and cols. (13) found decreased TSH levels in acromegalic patients with nodular goiter.

In this study, the frequency of thyroid cancer in acromegalic patients was $3.8 \%$, which may be underestimated because three patients had not yet undergone surgery. This frequency is approximately 300 times higher than the one reported in the overall Brazilian population (30), and in the majority of studies that have evaluated thyroid cancer in acromegalic patients (5,8,10,15,31-33). Balkany and Cushing (17) and Marchisotti and cols. (34) found an approximately $3 \%$ prevalence of thyroid cancer in acromegalic patients, which is similar to our findings. Tita and cols. (14) described seven cases of thyroid cancer in 125 acromegalic patients $(5.6 \%)$. The use of routine ultrasonography might explain the higher frequency of thyroid cancer in acromegalic patients described in recent studies. However, dos Santos and cols. (35) demonstrated a significantly increased prevalence of thyroid cancer in acromegalic patients compared with a control group. The study by dos Santos and cols. included 124 acromegalic patients from northeast Brazil and 263 ageand sex-matched control subjects. Nine acromegalic patients presented thyroid carcinoma (7.2\%), and only two $(0.7 \%)$ in the control group, which confirmed the higher prevalence of thyroid carcinoma in acromegaly. Rogozinski and cols. found four cases of differentiated thyroid carcinoma among 34 acromegalic patients (11\%) (24).

In this study, the patients with diffuse or nodular goiter that presented active acromegaly had greater thyroid volume than the patients with adequately treated acromegaly. This finding suggests that sustained exposure to high GH and IGF-I levels has a role in goiter development in the acromegalic population.

In conclusion, this study confirms the high frequency of benign thyroid diseases in acromegalic patients. The prevalence of thyroid cancer was greater than expected for the overall population, which strongly supports the indication of routine thyroid ultrasonography in patients with acromegaly.

Disclosure: no potential conflict of interest relevant to this article was reported.

\section{REFERENCES}

1. Melmed S. Acromegaly. N Engl J Med. 1990;322:966-77.

2. Dekkers OM, Biermasz NR, Pereira AM, Romijn JA, Vandenbroucke JP. Mortality in acromegaly: a metaanalysis. J Clin Endocrinol Metab. 2008;93:61-7.

3. Wright AD, Hill DM, Lowy C, Fraser TR. Mortality in acromegaly. Q J Med. 1970;39:1-16.

4. Alexander $L$, Appleton D, Hall R, Ross WM, Wilkinson R. Epidemiology of acromegaly in the Newcastle region. Clin Endocrinol. 1980;12:71-9.

5. Nabarro JDN. Acromegaly. Clin Endocrinol. 1987;26:481-512.

6. Bengtsson B, Eden S, Ernest I, Oden A, Sjogren B. Epidemiology and long-term survival in acromegaly. A study of 166 cases diagnosed between 1955 and 1984. Acta Med Scand. 1988;223:327-35.

7. Rajasoorya C, Holdaway IM, Wrightson P, Scott DJ, Ibbertson HK. Determinants of clinical outcome and survival in acromegaly. Clin Endocrinol. 1994;41:95-102.

8. Orme SM, Mcnally RJQ, Cartwright RA, Belchetz PE. Mortality and cancer incidence in acromegaly: a retrospective cohort study. J Clin Endocrinol Metab. 1998;83:2730-4.

9. Barzilari J, Heatley GJ, Cushing GW. Benign and Malignant tumors in patients with acromegaly. Arch Intern Med. 1991;151(8):1629-32.

10. Popovic V, Damjanovic S, Micic D, Nesovic M, Djurovic M, Petakov M; and the Pituitary Study Group. Increased incidence of neoplasia in patients with pituitary adenomas. Clin Endocrinol. 1998;49:441-5.

11. Jenkins PJ, Besser M. Clinical perspective: acromegaly and cancer: a problem. J Clin Endocrinol Metab. 2001;86(7):2935-41.

12. Cheung NW, Boyages SC. The thyroid gland in acromegaly: an ultrasonographic study. Clin Endocrinol. 1997;46:545-9.

13. Kasagi K, Shimatsu A, Miyamoto S, Misaki T, Sakahara H, Konishi J. Goiter associated with acromegaly: sonographic findings of the thyroid gland. Thyroid. 1999;9:792-6.

14. Tita $P$, Ambrosio MR, Scollo $C$, Carta A, Gangemi $P$, Bondanelli $M$, et al. High prevalence of differentiated thyroid carcinoma in acromegaly. Clin Endocrinol. 2005;63:161-7.

15. Gasperi M, Martino E, Manetti L, Arosio M, Porretti S, Faglia G, et al. Prevalence of thyroid diseases in patients with acromegaly: results of an Italian multicenter study. J Endocrinol Invest. 2002;25:240-5.

16. Herrmann BL, Baumann $H$, Janssen OE, Görges R, Schmid KW, Mann K. Impact of disease activity on thyroid disease in patients with acromegaly: basal evaluation and follow up. Exp Clin Endocrinol Diabetes. 2004;112:225-30.

17. Balkany $\mathrm{C}$, Cushing GW. An association between acromegaly and thyroid carcinoma. Thyroid. 1995;5:47-50.

18. Cannavò $S$, Squadrito $S$, Finocchiaro MD, Curtò L, Almoto $B$, Vieni $A$, et al. Goiter and impairment of thyroid function in acromegalic patients: basal evaluation and follow-up. Horm Metab Res. 2000;32(5):190-5.

19. Kurimoto M, Fukuda I, Hizuka N, Takano K. The prevalence of benign and malignant tumors in patients with acromegaly in a single institute. Endocr J. 2008;55(1):67-71.

20. Miyakawa M, Saji M, Tsushima M, Wakai K, Shizume K. Thyroid volume and serum thyroglobulin levels in patients with acromegaly: correlation with plasma insulin-like growth factor I levels. J Clin Endocrinol Metab. 1988;67(5):973-8.

21. DerwahI M, Broecker M, Kraiem Z. Clinical review 101: thyrotropin may not be the dominant growth factor in benign and malignant thyroid tumors. J Clin Endocrinol Metab. 1999;84:829-34.

22. Ruchala M, Skiba A, Gurgul E, Uruski P, Wasko R, Sowinski J. The occurrence of thyroid focal lesions and a need for fine needle 
aspiration biopsy in patients with acromegaly due to an increased risk of thyroid cancer. Neuro Endocrinol Lett. 2009;30(3):382-6.

23. Cheung NW, Boyages SC. Increased incidence of neoplasia in females with acromegaly. Clin Endocrinol. 1997;47(3):323-7.

24. Rogozinski A, Furioso A, Glikman P, Junco M, Laudi R, Reyes A, et al. Thyroid nodules in acromegaly. Arq Bras Endocrinol Metab. 2012;56(5):300-4.

25. Elmlinger MW, Kühnel W, Weber MM, Ranke MB. Reference ranges for two automated chemiluminescent assays for serum insulin-like growth factor I (IGF-I) and IGF-binding protein 3 (IGFBP3). Clin Chem Lab Med. 2004;42:654-64.

26. Prando D. Anatomia ultrassonográfica normal da tireoide. In: Brandão LG.Tireóide e paratireóide: estudo de casos. São Paulo: Brandão LG; 2002. p. 311-6.

27. Cibas ES, Ali SZ. The Bethesda system for reporting thyroid cytopathology. Thyroid. 2009;19(11):1159-65.

28. Greene FL, Page D, Fleming ID, Fritz AG, Balch CM, Haller DG, et al. (eds). AJCC Cancer Staging Manual, 6th ed. Springer-Verlag; 2002. p. 77-87.

29. Wüster C, Steger G, Schmelzle A, Gottswinter J, Minne HW, Ziegler R. Increased incidence of euthyroid and hyperthyroid goiters independently of thyrotropin in patients with acromegaly. Horm Metab Res. 1991;23(3):131-4.

30. Coeli MC, Brito AS, Barbosa FS, Ribeiro MG, Sieiro APAV, Vaisman M. Incidência e mortalidade por câncer de tireóide no Brasil. Arq Bras Endocrinol Metab. 2005;49(4):503-9.

31. Kauppinen-Mäkelin $R$, Sane $T$, Välimäki MJ, Markkanen $H$, Niskanen L, Ebeling $T$, et al. Increased cancer incidence in acromegaly - A nationwide survey. Clin Endocrinol (Oxf). 2009;72:277-9.

32. Baris D, Gridley G, Ron E, Weiderpass E, Mellemkjaer L, Ekbom A, et al. Acromegaly and cancer risk: a cohort study in Sweden and Denmark. Cancer Causes Control. 2002;13:395-400.

33. Barzilari J, Heatley GJ, Cushing GW. Benign and malignant tumors in patients with acromegaly. Arch Intern Med. 1991;151(8):162932.

34. Marchisotti FG, Umeda LM, Zach PL, Saldanha MD, First OS, Liberman B. [Acromegaly and thyroid disease: prevalence of thyroid cancer]. Arq Bras Endocrinol Metabol. 2005;49(5):843-9.

35. dos Santos MC, Nascimento GC, Nascimento AG, Carvalho VC, Lopes MH, Montenegro R, et al. Thyroid cancer in patients with acromegaly: a case control study. Pituitary. 2013;16(1):109-14. 